\title{
New record of bilateral hyperdontia in Carollia brevicauda (Chiroptera: Phyllostomidae)
}

\author{
Diego Esquivel-Melo*1, Diana Camelo-Pinzón ${ }^{1}$ and Abelardo Rodríguez-Bolaños ${ }^{1}$ \\ ${ }^{1}$ Grupo de Investigación Biodiversidad de Alta Montaña (BAM), Universidad Distrital Francisco José de Caldas. Calle 26B N. 4-54. \\ Bogotá D, C., 110311, Colombia. Email: alejandroesquivel_98@hotmail.com (DAEM), anady_cp@hotmail.com (DKCP) and \\ mountainresearch@gmail.com (ARB). \\ * "Corresponding author"
}

Systematics and taxonomy of bats is based in part on the morphological characteristics of the teeth and dental formulas. However, sometimes dental abnormalities appear that involve changes in the shape and number of teeth which can lead to erroneous taxonomic identifications. Numerous cases of dental anomalies have been reported for all groups of mammals, especially bats, the group with the most dental anomalies reported. This note presents a rare case of bilateral hyperdontia in Carollia brevicauda, for which only cases of oligodontia had previously been registered. The dental anomaly was found in a male specimen of silky short-tailed bat from the middle basin Rio Guayuriba, Acacias, Meta, Colombia. The unusual individual shows an additional incisor annexed to each normal external incisor in the maxilla, with separate alveoli, for a total of 6 upper incisors, two more than normal. The extra teeth have a morphology similar to the external incisors characteristic of the species, short and rounded, and are located between the canine and the second (external) upper incisor on each side of the head. No other specimen among 66 individuals of the same species showed a dental anomaly. This is the first record of bilateral hyperdontia for $C$. brevicauda. This dental anomaly may be due to an isolated mutation in this individual, because no other specimens with this type of anomaly were found in the study area.

La sistemática y taxonomía de los murciélagos está basada en parte sobre las características morfológicas de los dientes y sus fórmulas dentales. Sin embargo, a veces se presentan anomalías dentales que involucran cambios en la forma y número de los dientes lo cual puede llevar a identificaciones taxonómicas erróneas. Numerosos casos de anomalías dentales han sido reportados para todos los grupos de mamíferos, especialmente los murciélagos, el grupo con más anomalías dentales reportadas. Esta nota presenta un raro caso de hiperdontia bilateral en Carollia brevicauda, para el cual solamente casos de oligodontia han sido previamente registrados. La anomalía dental fue encontrada en un espécimen macho del murciélago de cola corta desde la cuenca media del Rio Guayuriba, Acacias, Meta, Colombia. El inusual individuo muestra un incisivo adicional anexo a cada incisivo externo normal en la maxila, con alveolos dentarios separados, para un total de seis incisivos superiores, dos más de lo normal. Los dientes extranumerarios tienen una morfología similar a los incisivos externos característicos de la especie, cortos y redondeados, y están localizados entre el canino y el segundo incisivo superior (externo) sobre cada rama maxilar. Ningún otro espécimen entre los 66 individuos de la misma especie mostró una anomalía dental. Este es el primer registro de hiperdontia bilateral para C. brevicauda. Esta anomalía dental puede deberse a una mutación aislada en este individuo, porque ningún otro espécimen con este tipo de anomalía fue encontrado en el área de estudio.

Keywords: bats; dental anomaly; incisor; polyodontia; supernumerary teeth.

@ 2017 Asociación Mexicana de Mastozoología, www.mastozoologiamexicana.org

\section{Introduction}

Systematics and taxonomy of bats is based in part on the morphological characteristics of teeth and dental formulas (Ramírez-Pulido and Müdespacher 1987; Rui and Drehmer 2004; Lanza et al. 2008; Cirranello et al. 2016). Abnormal dental formulas occur infrequently in natural populations of bats. However, when supernumerary teeth are present, the attendant changes in the shape and number of teeth can sometimes lead to erroneous taxonomic identifications.

There are mainly two types of anomalies in the number of teeth in mammals: polyodontia and oligodontia (López-Aguirre 2014). The first anomaly is rarer than the second (Lanza et al. 2008). Polyodontia, also called hyperdontia, hyperdoncia, third set of teeth, extra teeth, or polidontismo (Rodriguez and Cerviño 2009) can be caused by: 1) the creation and subsequent development of an additional tooth germ caused by expressions of rare genes. 2) The complete division of a tooth germ caused by mutations or changes in the genetic control of the development of teeth (Wolsan 1984). 3) By isolated mutations that could cause abnormalities to proteins such as Sonic hedgehog (Shh) that are responsible for normal development of molars and incisors, resulting in abnormal locations and stunted growth of these teeth (Dassule et al. 2000).

Numerous cases of dental anomalies have been reported for many groups of mammals, such as felids (Lynx lynx; Gomerčić et al. 2009), marsupials (Dromiciops gliroides, Rhyncholestes raphanurus; Martin 2007), cervids (Cervus elaphus hispanicus; Azorit et al. 2002), rodents (Hystrix cristata, Necromys lasiurus; Angelici and Luiselli 1999; Libardi and Percequillo 2014), pinnipeds (Arctocephalus australis, A. tropicalis, Otaria flavescens; Loch et al. 2010) and bats (Artibeus lituratus, Epomophorus wahlbergi; Rui and Drehmer 2004; Lanza et al. 2008) among others.

Bats are the group with most dental anomalies among mammals. López-Aguirre (2014) recorded 64 species of bats with dental anomalies, which predominate in insectivorous 
species, especially those belonging to the genus Myotis. The same author mentions that in the family Phyllostomidae, twenty-two species with dental anomalies have been reported, followed by Vespertilionidae and Pteropodidae with 18 and 17 species, respectively. This note presents a rare case of bilateral hyperdontia in Carollia brevicauda, a species whose characteristic dental formula (I 2/2, C 1/1, PM 2/2, M 3/3) is affected here in the normal number of incisors.

\section{Material and methods}

The specimen of Carollia brevicauda was collected during a study in the piedmont plains on the bat assembly of species present in the middle basin of the Rio Guayuriba, Acacias Meta, Colombia. The catch was made in March 2014, in the village Portachuelos $\left(4.18090^{\circ} \mathrm{N},-73.80998^{\circ} \mathrm{W}\right)$ at $1,708 \mathrm{~m}$ elevation using mist nets set in a patch of tropical moist forest. Additionally, 25 bat species were recorded with Carollia being the most abundant genus with 197 captures. C. brevicauda was recorded on 66 occasions with 23 being collected, only one of which having the described dental anomaly. This individual was deposited in the Collection of Mammals of the Natural History Museum of the Francisco José de Caldas University (MHNUD) under catalog number 921.

\section{Results}

The aberrant individual has an additional incisor adjacent to each normal external incisor in the maxilla, with separate alveoli, for a total of six upper incisors, two more than normal (Figure 1). It is an adult male, and thus has a degree of cranial sutures with an advanced degree of ossification, and little wear on tooth cusps. However, the evidence from the following morphometric measurements (in $\mathrm{mm}$ ) is sufficient to determine that it is an adult (Morris 1972): total length (TL): 64.0, wingspan (W): 309.0, forearm length (FA): 39.2, ear length

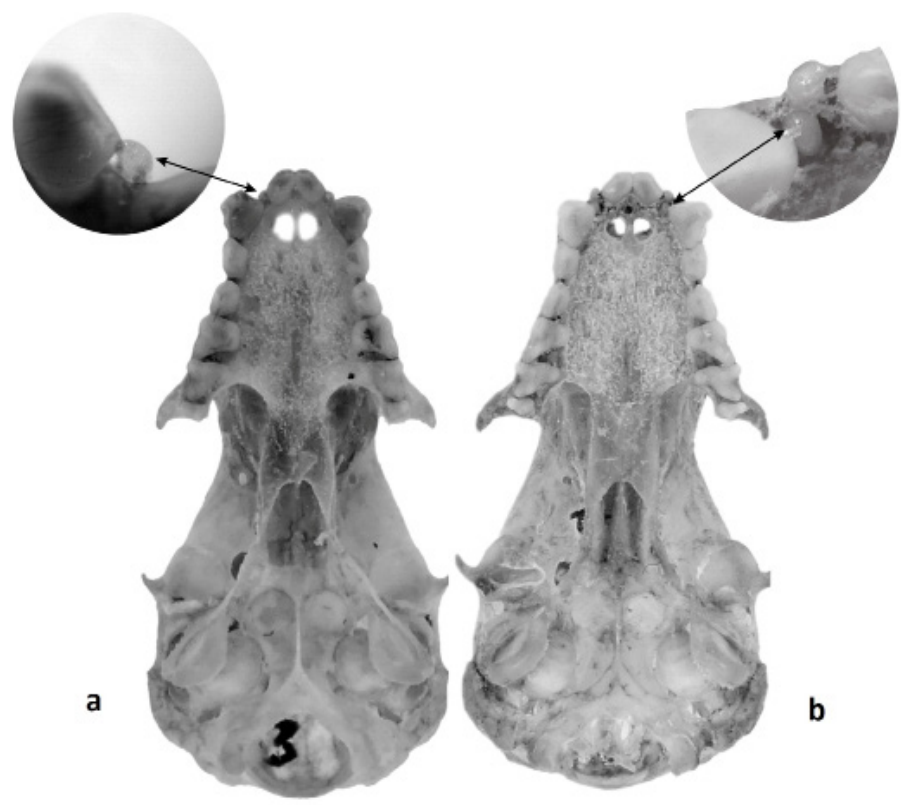

Figure 1. a) Ventral view of the cranium of specimen MUD 863, detailing the typical external incisors in Carollia brevicauda. b) Ventral view of the skull of specimen MUD 921, detailing the extranumerary incisors.
(E): 18.6, noseleaf $(N)$ : 8.0, foot length (FL): 9.8, tibia: 13.0, calcaneus: 4.6 and body weight $18.6 \mathrm{~g}$.

\section{Discussion and conclusions}

This is the first record of bilateral hyperdontia for this species. Previously, only cases of oligodontia had been reported for Carollia brevicauda (López-Aguirre 2014). The extra numerary teeth have a morphology similar to the external incisors characteristic of the species, short and rounded (Figure 1a) and are located between the canine and the second upper incisor (external) on each side of the upper jaw (Figure 1b).

This dental anomaly may be due to an isolated mutation present in this one individual, and without a permanent presence in the population since no other specimens with this type of anomaly were found in the study area. More likely, this is an example of the reappearance of an ancestral trait (atavism) caused by a shift in developmental patterning.

\section{Acknowledgements}

Special thanks go to S. Solari for her observations and comments on this manuscript and to S. Peña and D. Ramos for their valuable contributions.

\section{Literature cited}

Angelicl, F. M., AND L. LUISELLI. 1999. Extra teeth and dental anomalies in the crested porcupine Hystrix cristata, from Sicily. Acta Theriologica 44:219-223.

Azorit, C., Muñoz-Cobo, J., AND M. Analla. 2002. Abnormal teeth in the Spanish red deer (Cervus elaphus hispanicus). Zeitschrift für Jagdwissenschaft 48:252-260.

Cirranello, A., N. B. Simmons, S. Solari, and R. J. Baker. 2016. Morphological diagnoses of higher-level phyllostomid taxa (chiroptera: phyllostomidae). Acta Chiropterologica 18:39-71. Dassule, H. R., P. Lewis, M. Bei, R. Maas, and A. P. Mcmahon. 2000. Sonic hedgehog regulates growth and morphogenesis of the tooth. Development 127:4775-4785.

GomerČIć, T., G. Gužvica, M. Duras, J. Kusak, M. SindičIĆ, And D. Huber. 2009. Variation in teeth number, teeth and skull disorders in Eurasian lynx, Lynx lynx from Croatia. Folia Zoological 58:5765.

Lanza, B., Riccucci, M., And U. Funalolı. 2008. An interesting case of polyodontia in Epomophorus wahlbergi, with a review of this dental anomaly in bats (Chiroptera). Lynx series nova 39:109-127.

Libardi, G. S., and A. R. Percequillo. 2014. Supernumerary teeth in Necromys lasiurus (Rodentia, Cricetidae): the first record in sigmodontinae. Mastozoología neotropical 21:219-229.

Loch, C., P. C. Simões-Lopes, and C. J. Drehmer. 2010. Numerical anomalies in the dentition of southern fur seals and sea lions (Pinnipedia: Otariidae). Zoologia (Curitiba) 27:477-482.

Lopez-Aguirre, C. 2014. Dental anomalies: New cases of Artibeus lituratus from Colombia and a review of these anomalies in bats (Chiroptera). Chiroptera Neotropical 20:1271-1279.

Martin, G. M. 2007. Anomalías en la dentición de Dromiciops gliroides (Microbiotheria, Microbiotheriidae), Caenolestes fuliginosus and Rhyncholestes raphanurus (Paucituberculata, Caenolestidae). Revista Chilena de Historia Natural 80:393-406. 
MoRRIS, P. 1972. A review of mammalian age determination methods. Mammal Review 2:69-104.

RAmirez-PULIDO, J., AND C. MUdeSPACHER. 1987. Formulas dentarias anormales en algunos murciélagos mexicanos. Acta Zoológica Mexicana (n. s.) 23:1-54.

Rodríguez Romero, F. J., and S. Cerviño Ferradanes. 2009. Múltiples dientes supernumerarios distomolares. Avances en Odontoestomatología 25:319-325.

RuI, A. M., AND C. J. Drehmer. 2004. Anomalías e variações na fórmula dentária em morcegos do gênero Artibeus Leach (Chiroptera, Phyllostomidae). Revista Brasileira de Zoología 21:639-648.

WolsAn, M. 1984. The origin of extra teeth in mammals. Acta Theriologica 29:128-133.

Associated editor: William Lidicker

Submitted:September 23, 2016; Reviewed: November 25, 2016;

Accepted: December 30, 2016; Published on line January 15, 2017. 
74 THERYA Vol. 8(1): $71-73$ 